ИЗВЕСТИЯ АКАДЕМИИ НАУК ЭСТОНСКОН ССР. ТОМ 32 ГЕОЛОГИЯ. 1983, № 4

\title{
ЛИТОЛОГИЧЕСКАЯ КЛАССИФИКАЦИЯ ПОРОД ПРОМЫШЛЕННОЙ ПАЧКИ КУКЕРСИТА
}

Органическое вещество (ОВ) в ордовикских осадочных породах Эстонии довольно широко распространено. К породам с высоким содержанием концентрированного ОВ следует отнести аргиллитовые (т. н. диктионемовые) сланцы в нижнем и кукерситы в среднем ордовике.

Несмотря на то, что кукерситы уже давно разрабатываются и представляют значительный практический и научный интерес, до сих пор отсутствует общепринятая классификация пород промышленной пачки кукерсита. Такое положение, разумеется, затрудняет не только полноценное литологическое описание, но и взаимопонимание занимающихся геологической документацией и изучением пород промышленной пачки или обобщением фондовых материалов. Хотя кукерситы имеют тесную парагенетическую связь с известняками, содержащие OB породы не нашли рассмотрения в классификации карбонатных пород («Единая классификация ...., 1965).

Некоторые попытки классифицировать породы промышленной пачки кукерсита оказались неудачными, так как предложенные классификации неполны (Насонова, 1962) или основываются на визуальном учете составляющих породы компонентов. Последние классификационные схемы, рекомендованные для полевого определения пород, имеются лишь в рукописях С. Баукова * и поэтому мало известны. Весыма схематичны также предложенные аналогичные классификации пород промышленной пачки кукерсита Ленинградского месторождения (Данилова и др., 1973; Дубарь, Левин, 1973).

В классификации пород промышленной пачки кукерсита Н. М. Насоновой (1962) выделены 4 типа горючих сланцев, а также 4 типа карбонатных пород. Хотя эта классификация составлена с учетом химических анализов пород всей промышленной пачки, она, к сожалению, не охватывает всего многообразия состава пород этой пачки. Например, не учтены горючие сланцы с содержанием карбонатного компонента 25-35 и выше 40\%. Как показывают многочисленные химические анализы, большая часть кукерситов промышленной пачки содержит именно от 20 до $40 \%$ карбонатного материала. Таким образом, в эту классификацию не вошли самые распространенные разновидности кукерсита. Что касается типов карбонатных пород, то неясны даже принцип их выделения и возможные пределы изменчивости состава. Ни в той, ни в другой классификации не учтены породы с содержанием ОВ $15-25 \%$. Непригодность классификации Н. М. Насоновой для практического иопользования становится очевидной при изображении выделенных ею типов пород на треугольной диаграмме (рис. 1), где состав кукерсита четырех типов обозначен полями, которые покрывают лишь небольшую часть поля, соответствующего разбросу анали-

* Бауков С. Фациальные условия сланценакопления в среднем ордовике Прибалтики. Отчет в архивах ИГ АН ӘССР. Таллин, 1966. 


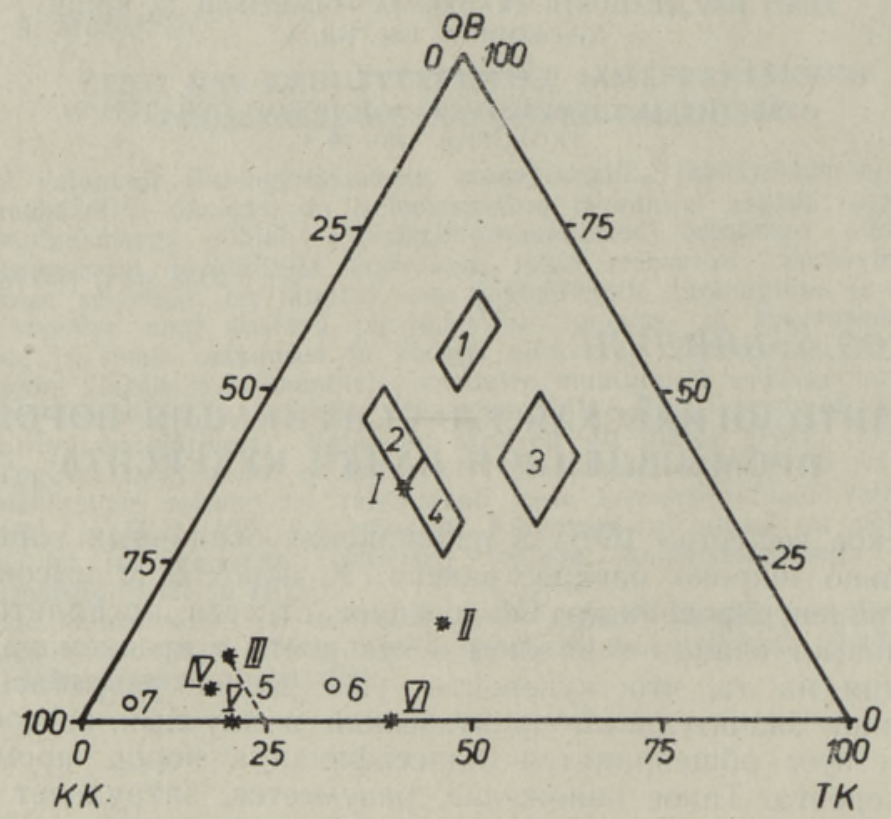

Рис. 1. Схемы классификации пород промышленной пачки кукерсита по Н. М. Насоновой (1962) и по Г. П. Дубарю и А. С. Левину (1973). 1-7 - Типы пород по Н. М. Насоновой. 1-4 - горючие сланщы: 1 - известковистый, 2 известковый, 3 - известково-глинистый, 4 - глинистоизвестковый $5-7-$ карбонатные породы: $5-$ глинистый известняк, 6 - мергель, 7 - доломит. ТК - терригенный компонент; КК - карбонатный компонент.

I-VI - Типы пород по Г. П. Дубарю и А. С. Левину. I - горючий сланец, II - горючий сланец глинистый, III - известняк керогенсодержащий розовый, IV - известняк керогенсодержащий серовато-розовый, V - глинистый известняк, VI - мергель.

зов (рис. 2). Доломит и мергель обозначены точками, глинистый известняк - линией, а глинистый известняк с примесью органического вещества из-за ошибочного суммарного состава трех компонентов $(90 \%)$ не удалось наметить на диаграмме.

Довольно подробная характеристика пород кукерситоносной толщи представлена в рукописях С. Баукова. По полевым макроскопическим описаниям на основании визуального учета количества ОВ он выделяет 7 разновидностей пород: 2 разновидности кукерсита, 2 мергеля и 3 известняка. Но и классификация С. Баукова не охватывает всю известную ныне изменчивость кукерситов и керогенсодержащих пород.

Классификационные схемы пород промышленной пачки кукерсита Ленинградского месторождения основаны также на макроскопически выделяемых литологических типах пород (Данилова и др., 1973; Дубарь, Левин, 1973). В обеих классификациях выделены 6 типов пород, но без характеристики пределов вариации состава. Приведенные в этих классификациях усредненные значения компонентного состава пород отличаются только в деталях, небольшие расхождения имеются и в наименованиях пород, но существенных различий между этими классификациями нет. На рис. 1 дано сопоставление классификации Г. П. Дубаря и А. С. Левина с классификацией Н. М. Насоновой, которое наглядно показывает, что типы пород, слагающие сланценосную толщу Ленинградского месторождения горючих сланцев, по сред- 


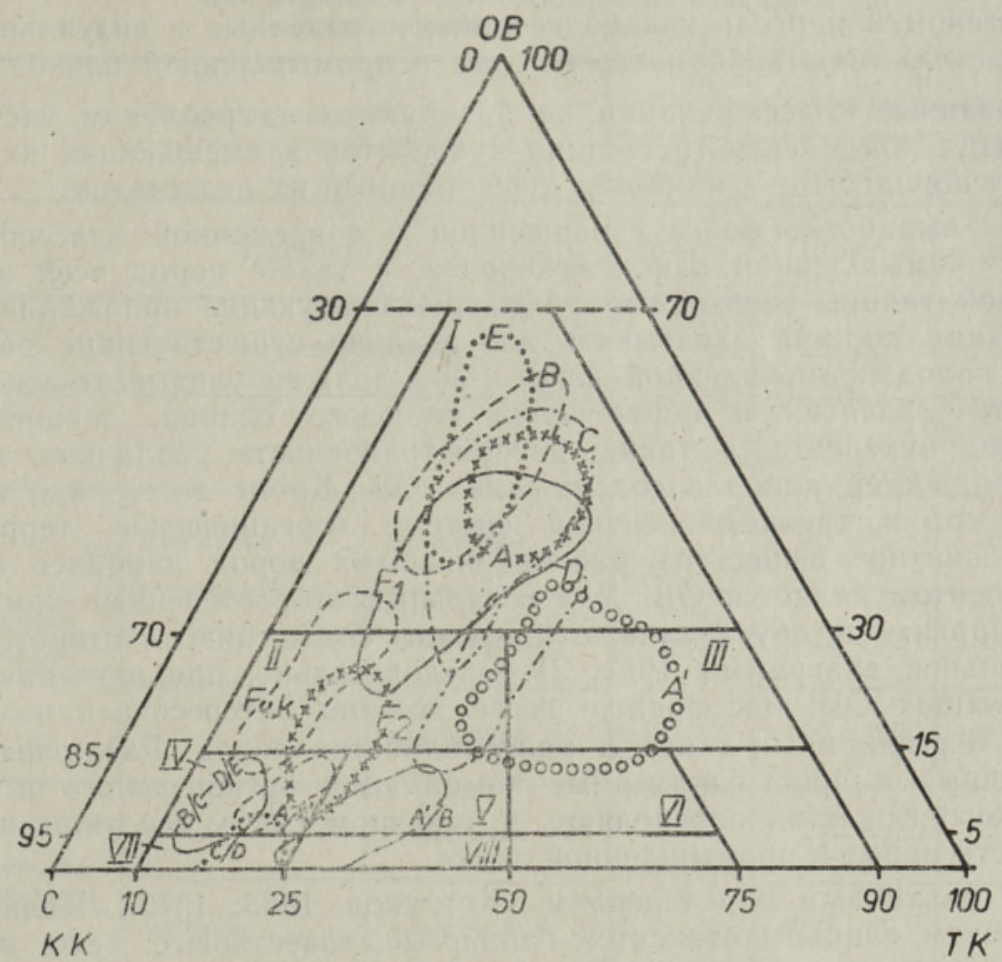

Рис. 2. Классификация пород промышленной пачки кукерсита и вещественный состав отдельных слоев промышленной пачки. Слои $\mathrm{A}, \mathrm{B}$, $\mathrm{C}, \mathrm{E}$ и $\mathrm{F}_{1}$ - кукерситы; слой $\mathrm{A}^{\prime}$ - глинистый кукерсит; слои $\mathrm{D}, \mathrm{F}_{2}$ и $\mathrm{F}$ ч. к. (чертова кожа) - известковый кукерсит; слои $\mathrm{B} / \mathrm{C}, \mathrm{D} / \mathrm{E}$ и $\mathrm{A} / \mathrm{A}^{\prime}$ - глинистый керогеновый известняк; слой $\mathrm{C} / \mathrm{D}$ - керогенистый глинистый известняк; слой $\mathrm{A}^{\prime} / \mathrm{B}$ - керогеновый или керогенистый известковый мергель.

нему содержанию компонентов не совпадают с центрами полей соответствующих типов пород, выделенных Н. М. Насоновой. Описанные выше схемы по Ленинградскому месторождению ввиду отсутствия пределов вариации компонентов, являются в строгом понимании не классификациями, а скорее всего, номенклатурным списком выделяемых в практике типов пород с характеристикой среднего (или наиболее типичного) содержания трех компонентов в них.

Из всего вышесказанного следует, что:

1) все описанные классификации представляют собой попытки выделить в промышленной пачке кукерсита типы пород по макролитологическим признакам и визуальному учету в них количества компонентов;

2) кукерсит в большинстве случаев определен по минимальному содержанию ОВ $15 \%$;

3) во всех классификациях наряду с чистым кукерситом выделена его глинистая разновидность, но состав последней в различных классификациях значительно отличается;

4) визуальному опознанию карбонатных разновидностей кукерсита препятствует, по всей вероятности, их внешнее сходство с чистыми кукерситами;

5) во всех классификациях выделены глинистый известняк, известняк 
с керогеном и мергель как более распространенные и визуально четко выделяемые типы карбонатных пород в промышленной пачке;

6) указанные классификации не базируются на реальном учете многообразия компонентного состава кукерситов и вмешающих их карбонатных пород. Это - наиболее существенный их недостаток.

При выработке более совершенной и современной классификации пород промышленной пачки кукерсита, а также пород всей кукерситоносной толщи, необходимо учитывать следующие положения. Классификация должна охватывать все реально существующие разновидности пород промышленной пачки. Она должна учитывать уже общепринятые понятия и определения горючего сланца, специфические свойства кукерсита, а также распространенность различных типов и разновидностей пород с содержанием ОВ. Кроме того, надо иметь в виду, что в трехкомпонентной системе (органическое, терригенное и карбонатное вещества) рассматриваемых пород наиболее важным компонентом является ОВ. Два остальных второстепенных компонента равноправны и обусловливают осевую симметрию соответствующей треугольной диаграммы (рис. 2). Следовательно, при изучении пород, содержащих ОВ, нас прежде всего должно интересовать количество $\mathrm{OB}$ в тех или иных типах и разновидностях пород. Различные количественные и пространственные комбинации органического и неорганического вещества определяют, в конечном счете, все типы и разновидности пород в промышленной пачке.

По различным определениям (Котлуков, 1968; 1973; Левин, 1982), к горючим сланцам относятся глинистые, известковые, реже кремнистые осадочные породы, содержащие более $15 \%$ сапропелевого или гумусо-сапропелевого ОВ. Эта траница содержания ОВ учтена и нами при выделении кукерситов.

Так как кукерситы Прибалтийского бассейна тесно связаны с карбонатными породами, предлагаемая классификация керогенсодержащих пород промышленной ппачки кукерсита должна быть сопоставима с принятой в Эстонской ССР классификацией карбонатных пород. Для выработки представительной классификации пород промышленной пачки кукерсита на треугольную диаграмму были нанесены результаты более 500 химических анализов пород промышленной пачки как Әстонского, так и Ленинградского месторождений. Как видно на рис. 2, распределение соответствующих анализов дает четкое представление о распределении типов и разновидностей пород по выделенным в промышленной пачке слоям, а также о частоте встречаемости тех или иных типов и разновидностей пород. Распределение анализов на диаграмме и частота встречаемости тех или иных компонентов служит наиболее объективным критерием для выделения их типов и разновидностей.

В результате изучения компонентного состава пород промышленной пачки кукерсита при составлении классификации учитывались следующие особенности:

1) содержание в породе керогена от следов до 5\% не вызывает особых изменений качества или внешнего вида породы. Кероген расположен в этих случаях обычно мелкими рассеянными зернами или заполняет ходы илоедов. От такой примеси керогена порода может приобрести слегка желтоватый оттенок. Однако содержание ОВ до $5 \%$ считается довольно большим для осадочных пород, и чтобы отличить их от пород, совсем лишенных ОВ, их именование целесообразно дополнить термином «керогенистый. Дополнительные термины «керогенистый и «керогеновый» используются по примеру вышеупомянутой классификации карбонатных пород. Суффиксы указывают на относи- 
Классификация керогенсодержащих пород

промышленной пачки кукерсита

\begin{tabular}{|c|c|c|c|c|c|c|}
\hline \multirow{2}{*}{$\begin{array}{c}\text { Номер } \\
\text { типа } \\
\text { см. } \\
\text { рис. } 2\end{array}$} & & \multirow{2}{*}{\multicolumn{2}{|c|}{$\begin{array}{c}\text { Наименование типов } \\
\text { и разновидностей пород }\end{array}$}} & \multicolumn{3}{|c|}{ Содержание компонентов, \% } \\
\hline & & & & $\mathrm{OB}$ & KK & TK \\
\hline I & \multicolumn{3}{|c|}{ кукерсит } & $30-70$ & $10-60$ & $10-60$ \\
\hline II & \multirow{2}{*}{ кукерсит } & \multicolumn{2}{|c|}{ известковый } & \multirow{2}{*}{$15-30$} & $35-75$ & $10-42,5$ \\
\hline III & & \multicolumn{2}{|c|}{ глинистый } & & $10-42,5$ & $35-75$ \\
\hline IV & \multirow{3}{*}{$\begin{array}{l}\text { кероге- } \\
\text { новый }\end{array}$} & известняк & глинистый & \multirow{3}{*}{$5-15$} & $60-85$ & $10-25$ \\
\hline $\mathrm{v}$ & & \multirow{2}{*}{ мергель } & известковый & & $42,5-70$ & $25-47,5$ \\
\hline VI & & & глинистый & & $25-47,5$ & $42,5-70$ \\
\hline VII & \multirow{2}{*}{$\begin{array}{l}\text { кероге- } \\
\text { ннстый }\end{array}$} & известняк & глинистый & \multirow{2}{*}{$\begin{array}{l}\text { следы - } \\
.5\end{array}$} & $70-90$ & $10-25$ \\
\hline VIII & & мергель & известковый & & $47,5-75$ & $25-50$ \\
\hline
\end{tabular}

Пр и меч ан ие. КК - карбонатный компонент; ТK - терригенный компонент.

тельное содержание компонента, причем суффикс «-овый» обозначает бо́льшую меру (табл. 1);

2) если в породе более $5 \%$ керогена, она имеет бежевую (или розовую) окраску, а при ударе выделяется специфический запах. Кроме того, в специфических условиях эта порода может гореть, обладая теплотой сгорания до 4 МДж/кг ( 1000 ккал/кг). По этим особенностям породы, содержащие $5-15 \%$ керогена, причислены к керогеновым;

3) породы, содержащие более $15 \%$ керогена, отнесены к кукерситам. Среди кукерситов, содержащих от 15 до $30 \%$ ОВ, можно выделить (в зависимости от преобладания в минеральной части карбонатного или глинистого компонентов) известковые и глинистые разновидности;

4) кукерситы, в которых более $30 \%$ ОВ, выделены как собственно кукерситы, и различать в них глинистые и известковые разновидности практически нет необходимости, так как в большинстве случаев содержание терригенного и карбонатного материалов в них почти равное $(20-40 \%)$. С увеличением количества ОВ в кукерсите содержание карбонатного и терригенного компонентов уменьшается в равной мере (рис. 2);

5) при выделении разных типов чередующихся с кукерситом карбоэатных и терригенно-карбонатных пород за основу приняты принципы вышеуказанной классификации. При этом, типы карбонатных пород выделены по содержанию в них керогена, а терригенная и карбонатные составляющие служат основой выделения разновидностей этих типов (таблица). 
Вещественный состав отдельных слоев кукерсита и известняка по площади и по разрезу довольно постоянный и изменяется в зависимости от изменения фациальных условий. Раопределение результатов химических анализов определенных слоев на треугольной диаграмме четко ограничено полями. Например, изображение кукерсита слоев A, $\mathrm{B}, \mathrm{C}, \mathrm{E}$ и $\mathrm{F}_{1}$ охватывает поле собственно кукерсита, пласт. известняка $\mathrm{C} / \mathrm{D}$ состоит из керогенистого глинистого известняка, а прерывистые слои B/C и D/E и комки известняка в слоях кукерсита являются керогеновыми известняками. Такая выдержанность состава литолсгнческих типов пород по их простиранию служит убедительным доқазательством надежности выбранных нами принципов классификации. Выделенные типы и разновидности пород легко определяются опытным исследователем визуально при геологической документации буровых кернов или обнажений.

\section{Л И ТЕРА Т У Р А}

Данилова Г. А., Дубарь Г. П., Кирюков В. В., Майоров Н. Ф. Сланценосная толща и геология карста Ленинградского месторождения горючих сланцев. - В кн.: Горногеологическое значение карста на Ленинградском месторождении горючих сланщев. Л., 1973, 16-53.

Дубарь $Г$. П., Левин А. С. Особенности геологического строения и изучения Ленннградского месторождения горючих сланцев. - В кн.: Формации горючих сланцев. Таллин, 1973, 39-53.

Единая классификация и легенда карбонатных пород. Таллин, 1965.

Котлуков B. А. Горючие сланщы СССР и общие закономерности размещсния их месторождений. - В кн.: Геология и месторождения угля и горючих сланцев СССР. XI. М., 1968, 7-11.

Котлуков В. А. Введение. - В кн.: Формацин горючих сланцев. Таллин, 1973, 5-6. Левин А. C. Основные вопросы геологин месторождений горючнх сланцев. М., 1982. Насонова Н. М. Структурно-текстурные особенности пород промышленного пласта Эстонского месторождения горючих сланцев. - Тр. Ин-та геол. АН ЭССР. $\mathrm{X}, 1962,205-214$.

Ннститут геологии

Академии наук Эстонской ССР
Поступила в редакцию 10/IV 1983

Aasa AALOE, H. VIIDING

\section{KUKERSIIDI TOOTSA KIHINDI KIVIMITE LITOLOOGILINE KLASSIFIKATSIOON}

Kukersiidikihtide kauaaegsest geoloogilisest uurimisest hoolimata puudus senini tänapäeva nōuetele vastav tootsa kihindi kivimite litoloogiline klassifikatsioon. Varasemates klassifikatsioonides on kivimi tüüpe eristatud visuaalsete tunnuste alusel, arvesse vōtmata erineva koostisega kivimite levikut ja esinemissagedust.

Artiklis on esitatud tootsa kihindi kōikidest kihtidest kogutud 500 kivimiproovi analüüsi tulemustele tuginev klassifikatsioon, milles on silmas peetud kivimite tegelikku komponentkoostist (orgaaniline, karbonaatne ja terrigeenne aine) ning kivimi tüüpide leviku sagedust. Tootsas kihindis eristatud 3 kukersiidi ja 5 karbonaatkivimite tüüpi või erimit on kogemustega töötaja võimeline ka visuaalselt määrama. Kindlate kivimi tüüpide seos tootsa kihindi teatud kihtidega näitab klassifikatsiooni aluseks võetud printsiipide otstarbekust. 


\section{LITHOLOGICAL CLASSIFICATION OF ROCKS OF THE COMMERCIAL KUKERSITE BED}

In spite of long-standing investigations of the commercial kukersite bed, a classification of rocks, which would meet current requirements, is still lacking. In preceding classifications rocks were distinguished on the basis of visual symptoms, but the actual distribution and the frequency of occurrence of rocks was not taken into consideration.

This classification is based on the results of analyses of about 500 samples, collected in all layers of the commercial bed. The factual components (organic matter, carbonate and terrigenous material) and the frequency of the distribution of rocks are taken into account. Different types and varieties of rocks (3 types of kukersite and 5 types of carbonate rocks) are easy to determine by an experienced investigator. The connection of certain rock types with certain layers of the commercial bed refers to the suitability of principles serving as the basis for the classification.

\section{EESTI NSV TEADUSTE AKADEEMIAS}

\section{AKIADEEMIA 37. AASTAKOOSOLEK}

toimus 30. märtsil k. a. Keskse osa selle päevakorrast moodustasid president $\mathrm{K}$. Rebase, osakondade akadeemiksekretäride J. Kahki, G. Naani ja A. Raukase ning presiidiumi teadusliku peasekretäri $\mathrm{R}$. Hagelbergi ülevaated 1982. aasta tegevusest ja eelseisvatest ülesannetest. Läbirääkimistel võtsid sõna asepresident A. Köörna, akadeemikud N. Alumäe, P. Ariste, H. Haberman, H. Keres, A. Kipper, E. Lippmaa ja I. Opik ning korresp.-1. E. Parmasto.
Koosolekul anti üle doktoridiplomeid, rahvamajandussaavutuste näituse medaleid ja professori-kutsetunnistus ning premeeriti 1983. aasta üliōpilastööde võistluse vôitjaid.

Oksikasjalikum ülevaade aastakoosolekust, samuti seal vastuvõetud otsus on avaldatud «Toimetiste» ühiskonnateaduste, matemaatika-füüsika ja bioloogia seeria k. a. 4. numbris.

\section{AKAMEEMIA OLDKOGU KOOSOLEK 14. JUUNIL 1983}

Avasõnaga esines ENSV TA president Karl Rebane. Sellele järgnes kaks teaduslikku ettekannet.

ENSV TA korrespondentliige Olaf Eiseni ettekanne «Uurimusi kromatograafia ja massispektraalanalüüsi alal» käsitles ENSV TA instituutides sel alal läbiviidavaid uurimistöid.

ENSV TA korrespondentliige Mihkel Veiderma ettekanne «Looduslike fosfaatide lagundamine lämmastikhappega» puudutas ökonoomset meetodit kõrgefektiivsete väetiste saamiseks.

ENSV TA presiidiumi tegevusest 1983. aasta esimesel poolel informeeris koosolijaid presiidiumi teaduslik peasekretär Raimund Hagelberg.

Päevakorras olid veel organisatsioonilised küsimused. Akadeemia liikmeskond täienes kahe akadeemiku võrra. Salajasel hääletusel valiti akadeemikuteks senised korrespondentliikmed füüsikalise keemia alal Olaf Eisen ja anorgaanilise keemia alal Mihkel Veiderma.

Oksikasjalikum ülevaade üldkogu koosolekust, samuti seal vastuvõetud otsus ja valitud akadeemikute elulood avaldatakse «Toimetiste» ühiskonnateaduste, matemaatika-füüsika ja bioloogia seeria 1984. a. 1. numbris. 